\title{
PROTOKOL TATANAN KEHIDUPAN ERA BARU DI DESTINASI PARIWISATA PULAU NUSA PENIDA
}

\author{
I Gusti Bagus Wirya Gupta1, Nelsye Lumanauw ${ }^{2}$ \\ ${ }^{1}$ Fakultas Ekonomi \& Bisnis, Universitas Ngurah Rai \\ 2 Prodi Pengelolaan Konvensi \& Peristiwa, Politeknik Internasional Bali \\ email: wiryagupta@gmail.com, nelsye.lumanuw@pib.ac.id
}

\begin{abstract}
Abstrak: Pandemi Covid-19 telah membuat destinasi Nusa Penida terpuruk. Protokol tatanan kehidupan era baru memiliki peran penting dalam mempercepat pemulihan sektor pariwisata di daerah tersebut. Disiplin pengunjung, keterbatasan petugas, fasilitas di tempat wisata, restoran dan hotel menjadi tantangan tersendiri. Bagaimana menerapkan protokol kesehatan normal baru di Nusa Penida adalah tujuan dari penelitian ini. Penelitian ini menggunakan metode deskriptif untuk mengumpulkan dan meringkas data melalui pendekatan studi cross-sectional. Teknik pengumpulan data melalui observasi dan wawancara dengan informan berdasarkan purposive sampling serta pendekatan melalui studi cross sectional di masing-masing lokasi. Kesimpulan dari penelitian ini adalah pentingnya kedisiplinan dan kesadaran yang tinggi dalam melaksanakan protokoler kehidupan era baru di Nusa Penida khususnya tempat wisata, restoran dan hotel yang masih perlu didorong, untuk menjamin keselamatan wisatawan dan menjaga keberlangsungan hidup masyarakat. aktif dan terlindungi.
\end{abstract}

Kata Kunci: Daya Tarik Wisata; Destinasi Wisata; Protokol Kesehatan; New Normal; Cross Sectional

Abstract: The Covid-19 pandemic has plunged Nusa Penida as tourism destination. The new normal protocol has an important role in accelerating the recovery of the tourism sector in the area. Discipline of visitors, limited officers, facilities in tourist attractions, restaurants and hotels are challenges. How to implement the health protocol of new normal in Nusa Penida is the aim of this research. The research uses a descriptive method to collect and summarize data through a cross-sectional study approach. Data collection techniques through observation and interviews with informants based on purposive sampling as well as approaches through a crosssectional study in each location. The conclusion of this research is the importance of discipline and high awareness in implementing the new era of life protocol in Nusa Penida, especially tourist attractions, restaurants and hotels, which still need to be encouraged, to ensure the safety of tourists and to keep people active and protected.

Keywords: Tourist Attraction; Tourism Destination; Health Protocol; New Normal; Cross Sectional 


\section{PENDAHULUAN}

Protokol kebersihan, kesehatan, keselamatan dan kelestarian lingkungan atau Cleanliness, Health, Safety and Environmental Sustainability yang sering disingkat dengan CHSE menjadi komponen penting dalam pencegahan penularan Corona Virus Disease 2019 (Covid-19) di masa pandemi ini. Pariwisata menjadi industri yang paling berdampak, dikarenakan pembatasan perjalanan oleh berbagai negara guna mencegah penyebaran Covid-19. Penerapan protokol CHSE pada industri pariwisata penting dilakukan untuk memperkuat kepercayaan masyarakat dan wisatawan yang akan berkunjung di destinasi pariwisata.

Panduan operasional CHSE telah diatur dalam Keputusan Menteri Kesehatan Nomor HK.01.07/Menkes/382/2020 sebagai pedoman dalam melakukan sosialisasi dan penerapan kebersihan, kesehatan, keselamatan, dan kelestarian lingkungan demi meningkatkan keyakinan para pihak serta reputasi usaha dan destinasi pariwisata. Pedoman yang tertera dalam panduan operasional CHSE mengacu pada protokol dan ketentuan lain yang ditetapkan World Health Organization (WHO) dan World Travel \& Tourism Council (WTTC) dalam rangka pencegahan dan penanganan Covid-19.

Pulau Nusa Penida sebagai destinasi pariwisata yang terletak di sebelah Tenggara Pulau Bali merupakan sebuah kecamatan terluas dari empat kecamatan yang ada di Kabupaten Klungkung, dan menjadi tempat wajib dikunjungi saat wisatawan berada di Bali. Daya tarik utama pulau ini terletak pada keindahan pemandangan alam terutama objek wisata pantai dengan panorama pantai dan laut lepas yang menakjubkan. Objek wisata pantai yang menjadi tempat wajib dikunjungi saat wisatawan berada di pulau ini adalah Pantai Kelingking, Pasih Uug atau lebih dikenal dengan nama Broken Beach, Angel Billabong, Cyrstal Bay, Raja Lima, Diamond dan Atuh. Keindahan daya tarik wisata Nusa Penida semakin populer dengan adanya sebuah berita oleh situs perjalanan TripAdvisor dalam Traveler's Choice Awards 2019 yang menyebutkan Pantai Kelingking menjadi pantai terbaik kedua di Asia, pilihan wisatawan.

Pandemi Covid-19 telah membuat pariwisata Nusa Penida terpuruk. Langkah cepat dan tepat perlu segera diambil sebagai upaya untuk memulihkan industri pariwisata yang terkena dampak pandemi. Protokol tatanan kehidupan era baru berperan penting untuk percepatan pemulihan sektor pariwisata di daerah ini. Namun demikian, kedisiplinan pengunjung, keterbatasan petugas di lokasi, minimnya sarana prasarana, fasilitas dan kesadaran serta kepedulian pihak terkait di daerah tujuan wisata, restoran dan hotel menjadi tantangan dalam penerapan protokol kesehatan di destinasi pariwisata Nusa Penida.

Observasi melalui pendekatan study cross-sectional terhadap penerapan protokol tatanan kehidupan era baru, mencakup pertanyaan-pertanyaan seperti bagaimana sikap pengunjung di destinasi, fasilitas apa saja yang tersedia dan bagaimana penerapannya di daya tarik wisata, restoran, hotel. Jawaban atas 
pertanyaan-pertanyaan tersebut menggambarkan penerapan protokol yang berlangsung di destinasi. Adanya ketidaksesuaian antara tatanan protokol dan penerapannya di lapangan menunjukkan pentingnya penelitian ini dilakukan.

Bagaimana penerapan protokol tatanan kehidupan era baru di destinasi pariwisata Nusa Penida menjadi tujuan penelitian ini. Penelitian ini diharapkan bermanfaat khususnya bagi pengunjung, pengelola daya tarik wisata, restoran dan hotel untuk meningkatkan rasa kesadaran dan kepedulian terhadap kebersihan, kesehatan, keselamatan dan kelestarian lingkungan, demi menjamin keamanan wisatawan dan masyarakat setempat.

\section{METODE PENELITIAN}

Penelitian ini dilakukan selama tiga hari pada tanggal 18 sampai 20 November 2020 di Pulau Nusa Penida. Jenis penelitian yang digunakan adalah metode deskriptif guna mengumpulkan dan merangkum data untuk mendapatkan gambaran yang jelas melalui pendekatan study cross-sectional. (Siyoto \& Sodik, 2015) menyebutkan study cross-sectional adalah pendekatan observasi atau pengumpulan data sekaligus pada suatu saat (point time approach), artinya tiap subjek penelitian hanya diobservasi sekali saja dan pengukuran dilakukan terhadap status karakter atau variabel subjek pada saat pemeriksaan. Jenis data penelitian ini adalah kualitatif berupa uraian penerapan protokol tatanan kehidupan era baru di destinasi pariwisata Nusa Penida. Sumber data primer dan sekunder menjadi acuan selama proses penelitian ini. Data primer diperoleh dari informan, yaitu pengunjung, petugas di daya tarik wisata, restoran dan hotel. Adapun data sekunder berupa artikelartikel yang diperoleh dari publisitas.

Teknik pengumpulan data melalui wawancara dan observasi langsung ke lokasi. Wawancara dilakukan terhadap informan dengan purposive sampling sekaligus pendekatan melalui study cross-sectional di masing-masing lokasi. Data tekstual yang terkumpul, selanjutnya dianalisis dan disimpulkan berdasarkan panduan CHSE.

\section{Hasil Dan Pembahasan}

Pembahasan penelitian terhadap penerapan protokol tatanan kehidupan era baru di daya tarik wisata, restoran dan hotel. Observasi yang dilakukan pada penelitian ini terkait dengan unsur-unsur daya tarik wisata, yaitu what to see, what to do, what to arrive dan where to stay. Unsur what to buy tidak diobservasi mengingat situasi pandemi saat ini, tidak ada toko khusus souvenir yang buka di Nusa Penida.

\section{Protokol Kesehatan di Daya Tarik Wisata}

Penerapan protokol tatanan kehidupan era baru terhadap destinasi pariwisata diklasifikasikan sesuai dengan hasil observasi lapangan, yaitu: (1) pada pintu masuk, pengunjung memakirkan kendaraan sesuai dengan petunjuk dan aturan yang ada, (2) penyemprotan barang bawaan pengunjung menggunakan desinfektan atau cairan pembersih lain yang 
aman dan sesuai, sebelum memasuki area, (3) tersedianya tempat cuci tangan atau wastafel dengan air mengalir atau menggunakan hand sanitizer sendiri, (4) pengecekan suhu tubuh pengunjung menggunakan termogun, (5) tersedianya toilet/kamar mandi yang tetap dalam keadaan hygiene, bersih, kering dan tidak bau setelah dibersihkan, (6) tempat sampah tertutup, (7) jaga jarak minimal satu meter bagi pengunjung.

Observasi dilakukan terhadap unsur daya tarik what to see, what to arrive pada destinasi pariwisata Nusa Penida di objek-objek DTW, yaitu: Pantai Kelingking, Pasih Uwug atau lebih dikenal dengan nama Broken Beach, Angel Billabong, Crystal Bay, Raja Lima, Diamond dan Atuh.

Tabel 1

CHSE di Daya Tarik Wisata

\begin{tabular}{clccccccc}
\hline No & \multicolumn{1}{c}{ DTW } & $(1)$ & $(2)$ & $(3)$ & $(4)$ & $(5)$ & $(6)$ & $(7)$ \\
\hline 1 & Kelingking & $\sqrt{ }$ & - & - & - & $\sqrt{ }$ & - & $\sqrt{ }$ \\
\hline 2 & Broken Beach & $\sqrt{ }$ & - & - & - & - & $\sqrt{ }$ & $\sqrt{ }$ \\
\hline 3 & Angel's Bill. & $\sqrt{ }$ & - & - & - & $\sqrt{ }$ & $\sqrt{ }$ & $\sqrt{ }$ \\
\hline 4 & Crystal Bay & $\sqrt{ }$ & - & - & - & $\sqrt{ }$ & - & $\sqrt{ }$ \\
\hline 5 & Raja Lima & $\sqrt{ }$ & - & $\sqrt{ }$ & $\sqrt{ }$ & $\sqrt{ }$ & $\sqrt{ }$ & $\sqrt{ }$ \\
\hline 6 & Diamond & $\sqrt{ }$ & - & - & - & - & - & $\sqrt{ }$ \\
\hline 7 & Atuh & $\sqrt{ }$ & - & - & - & - & - & $\sqrt{ }$ \\
\hline
\end{tabular}

Sumber: CHSE Nusa Penida

Berdasarkan Tabel 1 dipahami bahwa protokol CHSE di destinasi pariwisata Nusa Penida masih belum diterapkan sepenuhnya. Berikut penerapan protokol CHSE di destinasi pariwisata Nusa Penida:

a. Area parkir pada ketujuh DTW tersedia cukup luas, sehingga pengunjung bisa memakirkan kendaraan sesuai dengan petunjuk dan aturan yang berlaku berupa tanda garis putih pemisah. Pada area parker yang belum permanen, pengunjung tetap melakukan parkir kendaraan dengan tertib.

b. Tidak dilakukan penyemprotan menggunakan desinfektan atau cairan pembersih lain yang aman dan sesuai, terhadap barang bawaan pengunjung saat memasuki area pada masing-masing DTW. Barang bawaan pengunjung berpotensi membawa virus yang bisa menyebar ke pengunjung lainnya.

c. Tidak ada pengecekan suhu tubuh terhadap pengunjung di enam DTW Kelingking, Broken Beach, Angel's Billabong, Crystal Bay, Diamond dan Atuh. Adapun di DTW Raja Lima, petugas di lokasi melakukan cek suhu terhadap pengunjung sebelum memasuki area. Suhu tubuh dan kondisi kesehatan pengunjung harus diperiksa sebagai persayaratan memasuki area, apabila diketemukan tidak sesuai dengan persyaratan maka selanjutnya harus mengikuti petunjuk dari pengelola daya tarik wisata.

d. Sarana tempat cuci tangan atau wastafel tidak tersedia pada keenam DTW, kecuali di DTW Raja Lima. Fasilitas tempat cuci tangan di DTW Raja Lima adalah milik dari rumah makan yang berada di lokasi tersebut. 
e. Toilet/kamar terdapat di DTW Kelingking, Angel's Billabong, Crystal Bay dan Raja Lima walau terkesan kurang bersih dan hygiene, sedangkan Broken Beach, Diamond dan Atuh tidak tersedia fasilitas tersebut.

f. Terdapat tempat sampah tidak tertutup di DTW Broken Beach dan Angel's Billabong, sedangkan DTW lainnya tidak tersedia tempat sampah. Kondisi ini memungkinkan pengunjung membuang sampah sembarangan.

g. Jaga jarak satu meter dilakukan oleh pengunjung yang tampak berada di ketujuh objek DTW. Pada saat melakukan photo bersama, pengunjung saling berdekatan dan kembali jaga jarak setelah pengambilan photo.

Tidak terpenuhinya beberapa tatanan pada protokol CHSE di beberapa objek DTW dikarenakan minimnya petugas yang berjaga di lokasi dan keterbatasan fasilitas yang dimiliki, di samping masih sepinya pengunjung selama pandemi Covid-19. DTW Raja Lima memiliki fasilitas lebih lengkap dibandingkan objek-objek lainnya. Hal ini dimungkinkan karena terdapat rumah makan di area masuk objek tersebut, sehingga pengelola berupaya menerapkan protokol CHSE guna menarik pengunjung dan menjaga kenyamanannya selama berada di lokasi.

\section{Protokol Kesehatan di Restoran}

Penerapan protokol tatanan kehidupan era baru terhadap restoran diklasifikasikan sesuai dengan observasi lapangan, yaitu (1) pengecekan suhu tubuh pengunjung menggunakan termogun, (2) tersedianya tempat cuci tangan atau wastafel dengan air mengalir, (3) tersedianya toilet/kamar mandi yang tetap dalam keadaan hygiene, bersih, kering dan tidak bau setelah dibersihkan, (4) tempat sampah tertutup, (5) duduk di kursi yang telah diatur dengan berjarak, (6) tidak menggunakan alat makan bersama, (7) karyawan menggunakan sarung tangan saat menyajikan makanan.

Observasi dilakukan terhadap unsur daya tarik what to do dalam hal ini tempat makan di destinasi pariwisata Nusa Penida terkait dengan fasilitas pada objek DTW, yaitu: Restoran Angel's Billabong, Minang Nusa dan Star Semabu. Ketiga restoran tersebut dipilih menjadi bagian dari objek penelitian dikarenakan menjadi tempat makan para peserta program We Love Bali oleh Kemeparekraf pada bulan Oktober dan November 2020, dengan demikian persyaratan sertifikasi CHSE seharusnya telah terpenuhi.

Tabel 2

CHSE di Restoran

\begin{tabular}{ccccccccc}
\hline No & Restoran & $(1)$ & $(2)$ & $(3)$ & $(4)$ & $(5)$ & $(6)$ & $(7)$ \\
\hline 1 & Angel's Bill. & $\sqrt{ }$ & $\sqrt{ }$ & $\sqrt{ }$ & $\sqrt{ }$ & $\sqrt{ }$ & $\sqrt{ }$ & - \\
\hline 2 & Minang Nusa & $\sqrt{ }$ & $\sqrt{ }$ & $\sqrt{ }$ & $\sqrt{ }$ & $\sqrt{ }$ & $\sqrt{ }$ & - \\
\hline 3 & Star Semabu & $\sqrt{ }$ & $\sqrt{ }$ & $\sqrt{ }$ & $\sqrt{ }$ & $\sqrt{ }$ & $\sqrt{ }$ & - \\
\hline \multicolumn{7}{c}{ Sumber: CHSE Nusa Penida } & &
\end{tabular}

Sumber: CHSE Nusa Penida 
Berdasarkan Tabel 2 dapat dipahami bahwa protokol CHSE di tiga restoran Nusa Penida, sebagian besar sudah diterapkan, yaitu sebagai berikut:

1. Ketiga restoran telah menerapkan salah satu tatanan, yaitu pengunjung yang memasuki area restoran mendapat pengecekan suhu tubuh.

2. Fasilitas tempat cuci tangan dengan air mengalir menggunakan sabun tersedia pada area masuk di ketiga restoran tersebut. Dengan demikian, mempermudah pengunjung untuk melakukan cuci tangan dengan baik dan benar.

3. Seluruh restoran menyediakan fasilitas toilet, namun demikian kebersihan dan higienitas perlu ditingkatkan. Pengunjung yang tidak menjaga kebersihan setelah menggunakan toilet tersebut dan tidak ada petugas khusus yang mengecek terutama di jam-jam tertentu, mengakibatkan tidak terjaganya kebersihan dan higienis.

4. Tempat sampah tertutup disediakan oleh pihak restoran. Hal ini memudahkan pengunjung untuk tertib membuang sampah bekas makanan dan tisu pada tempatnya.

5. Restoran memberikan tanda silang untuk tempat duduk yang tidak boleh diduduki pengunjung, dengan demikian posisi duduk pengunjung tetap berjarak dan terhindar dari kontak fisik dan penularan Covid-19.

6. Layanan makanan di setiap restoran disajikan dengan peralatan sendokgarpu yang ditutup tisu atau plastik. Peralatan makanan diberikan pada masing-masing pengunjung dan tidak diperkenankan untuk digunakan secara bersama-sama, serta tidak berbagi makanan minuman dengan orang lain.

7. Di ketiga restoran, tidak ada karyawan yang menggunakan sarung tangan saat menyajikan makanan kepada pengunjung. Hal ini bisa mengakibatkan kemungkinan tercemarnya makanan yang disajikan melalui tangan penyaji.

Penerapan protokol tatanan kehidupan era baru di restoran Nusa Penida sudah dilaksanakan dengan baik, kecuali penggunaan sarung tangan oleh pramusaji. Kelalain ini harus diperbaiki demi terjaganya hygiene, sanitasi dan keamanan makanan yang disajikan.

\section{Protokol Kesehatan di Hotel}

Penerapan protokol tatanan kehidupan era baru terhadap hotel diklasifikasikan sesuai dengan observasi lapangan, yaitu (1) pengecekan suhu tubuh pengunjung menggunakan termogun, (2) penyemprotan barang bawaan tamu menggunakan desinfektan atau cairan pembersih lain yang amain dan sesuai, sebelum memasuki area hotel, (3) tamu mengisi formulir self assessment risiko Covid-19, (4) di dalam kamar, toilet dalam keadaan higienis, bersih, kering, tidak bau dan berfungsi dengan baik, (5) di dalam kamar, tersedia tempat sampah tertutup, (6) di area publik, tamu mengikuti aturan posisi duduk yang telah ditetapkan, (7) tamu menggunakan perlatan ibadah/olah raga pribadi. 
Observasi dilakukan terhadap unsur daya tarik where to stay di destinasi pariwisata Nusa Penida yaitu Hotel Arsa Shanti, Wait Garden dan Sawit Garden. Ketiga hotel tersebut dipilih menjadi bagian dari obyek penelitian dikarenakan menjadi tempat menginap para peserta program $W e$ Love Bali oleh Kemenparekraf pada bulan Oktober dan November 2020, dengan demikian persyaratan sertifikasi CHSE seharusnya telah terpenuhi.

Tabel 3

CHSE di Homestay

\begin{tabular}{ccccccccc}
\hline No & Restoran & $(1)$ & $(2)$ & $(3)$ & $(4)$ & $(5)$ & $(6)$ & $(7)$ \\
\hline 1 & Arsha Shanti & $\sqrt{ }$ & - & - & $\sqrt{ }$ & $\sqrt{ }$ & $\sqrt{ }$ & $\sqrt{ }$ \\
\hline 2 & Wait Garden & $\sqrt{ }$ & - & - & $\sqrt{ }$ & $\sqrt{ }$ & $\sqrt{ }$ & $\sqrt{ }$ \\
\hline 3 & Sawit Garden & $\sqrt{ }$ & - & - & $\sqrt{ }$ & $\sqrt{ }$ & $\sqrt{ }$ & $\sqrt{ }$ \\
\hline \multicolumn{7}{c}{ Sumber: CHSE Nusa Penida }
\end{tabular}

Berdasarkan Tabel 3 dapat dipahami bahwa masih ada tatanan yang belum diterapkan hotel terkait penerapan protokol CHSE, yaitu:

1. Ketiga hotel melakukan pengecekan suhu tubuh kepada setiap pengunjung, sebelum memasuki area. Apabila ditemukan suhu $\geq 37,3 \circ \mathrm{C}$ ( 2 kali pemeriksaan dengan jarak 5 menit), tidak diperkenankan masuk kecuali memiliki hasil pemeriksaan negative/nonreaktif Covid-19 yang masih berlaku.

2. Tatanan membersihkan barang milik pengunjung dengan cara yang aman, menggunakan desinfektan/cairan pembersih lain yang aman dan sesuai sebelum dibawa masuk, tidak dilakukan oleh pihak hotel. Barang bawaan pengunjung bisa berpotensi membawa virus dan menyebar ke pengunjung lain atau orang-orang di sekitarnya. Oleh karenanya, penting bagi pihak hotel untuk waspada dan melakukan penyemprotan sebelum pengunjung memasuki area hotel atau kamar.

3. Pengunjung tidak diminta untuk mengisi formulir selfassessment risiko Covid-19 yang merupakan informasi mengenai kondisi kesehatan dan riwayat perjalanan dalam 14 hari terakhir. Selfassessment menjadi penting untuk memudahkan petugas hotel mengecek apakah pengunjung pernah berada di zona merah Covid-19, sehingga lebih cepat mengantisipasi apabila terjadi hal yang tidak diinginkan.

4. Di dalam kamar, terdapat toilet dalam keadaan higienis, bersih, kering, tidak bau dan berfungsi dengan baik. Pengunjung hotel lebih disiplin menjaga kebersihan kamarnya, di samping itu petugas hotel siap melakukan pembersihan kamar apabila diminta.

5. Tempat sampah tertutup tersedia di dalam kamar hotel yang memudahkan pengunjung untuk bersikap disiplin membuang sampah pada tempatnya.

6. Di area publik, tersedia tanda silang pada tempat duduk, sehingga pengunjung harus mengikuti aturan posisi duduk yang telah ditetapkan 
untuk menghindari kontak fisik dan penularan Covid-19.

7. Pengunjung hotel menggunakan peralatan ibadah/olah raga pribadi. Hal ini penting untuk ditaati sebagai upaya pencegahan penularan virus, mengingat kondisi seseorang tidak dapat diketahui dengan pasti, apakah dalam keadaan sehat atau tidak.

Penerapan protokol tatanan kehidupan era baru di ketiga hotel Nusa Penida sudah dilaksanakan, kecuali terhadap penyemprotan menggunakan desinfektan atau cairan pembersih lain yang aman dan sesuai pada barang bawaan pengunjung sebelum memasuki area hotel dan pengisian formulir selfassessment risiko Covid-19. Kedua tatanan dianggap penting guna meminimalisir pencegahan penularan Covid-19 baik untuk pengunjung tersebut maupun orang-orang sekitarnya.

\section{KESIMPULAN}

Pentingnya kedisiplinan dan kesadaran yang tinggi dalam penerapan protokol tatanan kehidupan era baru di Nusa Penida, khususnya pihak daya tarik wisata, restoran dan hotel masih harus terus digalakkan. Penerapan protokol tatanan kehidupan era baru penting guna mencegah terjadinya penularan Covid-19 dan menjamin keselamatan serta keamanan wisatawan yang berkunjung. Di samping itu, kesadaran diri terhadap penerapan protokol kesehatan akan membuat masyarakat setempat bisa tetap beraktivitas, namun sekaligus juga tetap terlindungi.

\section{SARAN}

Melalui penelitian ini, peneliti menyarankan kepada pemerintah daerah Klungkung atau perusahaan swasta melalui program Corporate Social Responsibility (CSR) untuk memberi bantuan kelengkapan fasilitas yang masih diperlukan guna memenuhi standar protokol tatanan kehidupan era baru, terutama di objek-objek daya tarik wisata. Adapun saran terhadap restoran dan hotel untuk segera memenuhi kelengkapan fasilitas sebagai persyaratan protokol tatanan kehidupan era baru.

\section{UCAPAN TERIMA KASIH}

Penulis menyampaikan terima kasih kepada rekan-rekan praktisi dari pihak hotel khususnya yang telah membantu pelaksanaan observasi pada daya tarik wisata, restoran dan hotel di Pulau Nusa Penida. Semoga pandemi Covid19 segera berlalu dan Pulau Nusa Penida kembali mendapat banyak kunjungan wisatawan domestik maupun mancanegara. 


\section{REFRENSI}

Siyoto, S., \& Sodik, M. A. (2015). Dasar metodologi penelitian. Literasi Media Publishing.

Badung, I Dewa Ayu Agung Intan Aspriyani. 2018. Strategi Pengembangan Nusa Penida Sebagai Salah Satu Destinasi Wisata Unggulan Kabupaten Nusa Penida Kabupaten Klungkung Provinsi Bali. Calyptra: Jurnal Ilmiah Mahasiswa Universitas Surabaya. 7(1)

Cai, Fang. 2020. Editor. China's Economic New Normal, Growth, Structure, and Momentum. Research Series on The Chinese Dream and China's Development Path. Singapore: Social Sciences Academic Press and Springer Nature Singapore.

Damayanti, Ida Ayu Kade Werdika, I Nengah Wijaya, I Nyoman Kanca. 2017. Strategi Pengembangan Pulau Nusa Penida Sebagai Kawasan Pariwisata yang Berkelanjutan. Soshum: Jurnal Sosial dan Humaniora, [S.1.], v. 5, n. 2, p. 136. ISSN 2580-5622.

Fajri, Devy Dwi. 2020. Pelatihan Penerapan Protokol Kesehatan Karyawan Hotel di Masa Tatanan Normal Baru. Jurnal Abdimas Pariwisata. Volume 1 No 2 Tahun 2020. eISSN 26857731

Kristina, Ni Made Rai. 2020. Pemulihan Ekonomi Pariwisata Bali di Era New Normal. Cultourse Jurnal Ilmiah Pariwisata Budaya Hindu. 1 (2), e-ISSN: 2745-7915. p-ISSN: 2745-7923 136

Lumanauw, Nelsye. 2020. Edukasi Dan Implementasi Protokol Clean Health Safety Environtment Melalui We Love Bali Kemenparekfraf Pada Program 10 Sanur-Nusa Penida-Nusa Lembongan-Sanur. Jurnal Ilmiah Hospitality Management. 11 (1:), 71-81.

Peraturan Menteri Pariwisata Republik Indonesia Nomor 14 Tahun 2016 Tentang Pedoman Pariwisata Berkelanjutan

Subhiksu, Ida Bagus Kade, Gusti Bagus Rai Utama. 2018. Daya Tarik Wisata Museum Sejarah Dan Perkembangannya di Ubud Bali. Bali: Penerbit Deepublish.

Supriadi, B. \& Roedjinandari, N. (2017). Perencanaan dan Pengembangan Destinasi Pariwisata. Malang: Universitas Negeri Malang. TripAdvisor Surfaces The Best Beaches In Asia With 2019 Travellers' Choice Awards. https://tripadvisor.mediaroom.com/press-releases?item $=126200$ diunduh tanggal 23 Desember 2020. 
Surat Edaran Nomor HK.01.07/Menkes/382/2020 tentang protokol kesehatan bagi masyarakat di tempat dan fasilitas umum dalam rangka pencegahan dan pengendalian corona virus disease 2019 (Covid-19)

Wisnawa, I Gede Yudi Wisnawa, I Gst Ngr Yoga Jayantara, I Kadek Gunawan. 2020. Pemetaan Sebaran Tingkat Potensi Objek Wisata Yang Terdapat Di Kecamatan Nusa Penida. Jurnal Enmap (Environment \& Mapping), Jurusan Geografi Fakultas Hukum Dan Ilmu Sosial Universitas Pendidikan Ganesha. ENMAP Vol. 1 No.2 September 2020. p-ISSN: 2745373 e-ISSN: 27453723. 